\title{
A STUDY OF THE GRADUATE THESES ON DISTANCE LEARNING ADMINISTRATION IN TURKEY FROM 1999 TO 2019
}

\author{
Dr. Eren KESIM \\ ORCID: 0000-0001-8360-128X \\ Faculty of Education \\ Anadolu University \\ Eskisehir, TURKEY
}

Received: 21/09/2019 Accepted: 11/11/2019

\begin{abstract}
This study covers 117 masters and 28 doctorate theses published between 1999-2019 in Turkey for a total of 145 theses on distance learning administration. Due to the goal of analyzing graduate theses published in the field of distance learning administration in Turkey between the years of 1999-2019, qualitative research method was used in this study. The distribution of subjects within these theses was found to focus on 6 main themes. These themes, in decreasing frequency, were services required by distance education institutions, analysis - evaluation studies, factors influencing distance education services, issues encountered in distance learning administration, recommendation studies, and comparative studies. The policy recommendations of research in distance learning administration focused on three categories. These categories, in decreasing frequency order, were policy recommendations towards services required by distance education institutions, policy recommendations regarding factors influencing distance education services, and policy recommendations regarding issues faced in distance learning administration. No other research, evaluating the research on distance learning administration in Turkey along with the policy recommendations made by these studies was encountered in the literature review. The other findings of this study are presented in a discussion regarding the findings of other studies in the literature.
\end{abstract}

Keywords: Educational administration, distance learning administration, distance education.

\section{INTRODUCTION}

The speed of the change process affects social institutions intensely. Education as a social institution is at the center of the change process. In other words, new technologies that have developed in the information society have become a strategic part of education. Today, the decisions taken with the use and management of technology have become more and more important for educational institutions with the intensive use of educational technologies in the provision of educational services. Developing new technologies provide important opportunities for educational organizations, especially in the process of solving the problems of education as a community service (Selwyn, 2016; Wheeler, 2015).

Today, educational administration represents an important area of profession. Educational administration as a profession, differs from public administration in some aspects in terms of its different characteristics. The most strategic point that highlights this difference is that education is directly related to individuals as a social institution (Aydin, 2014). Today, administration and education represent two important fields of science. Important opportunities based on the changes and research findings in these two areas, arise for educational institutions. Especially for the rational use of the possessed material and human resources, the field of educational administration was born with a unique structure and has been continued its development (Kaya, 2002, p.64).

The most important feature of educational administration is the application of administration to education. As an area of profession, educational administration aims to address the education system in general by starting from educational institutions and examining them as a whole. Education systems include institutions, education programs and budgets which are included in all formal and non-formal education at the national 
scale. Population change, economic structure of countries, administrators, teachers, students, parents and educational technologies are the basic factors that play a role in educational administration (Balci, 2019, pp.55-57).

As the change process affects all disciplines, it also directs the development dynamics of educational administration as an area of profession. In this process, the process of transporting education services to the society through schools especially in the future should certainly be shaped with the phenomenon of change. The current situation necessitates investigating the field of educational administration from different perspectives (Gedikoglu, 2015).

Developing new technologies are used extensively in educational organizations as in all organizations. Distance education institutions are also using new technologies that are developing due to the nature of the education service provided. In this way, an important opportunity emerges for the solution of potential problems in the provision of educational services. The provision of educational services through information and communication technologies in distance education institutions has made it necessary to highlight a new field of profession (Isman, 2011).

With the beginning of the restructuring of distance education services according to the diversified educational needs of individuals, the technologies used in educational services have also come to the forefront with an accelerating development process. The reality of providing the increasing educational needs effectively with new technologies increases the strategic importance of open and distance education as an area of profession (Firat, 2019).

Leadership for all educational institutions represents an indispensable philosophy. Administration of distance education institutions should be handled within the framework of unique dynamics due to the nature of distance education. The leadership role of distance education institution managers emphasizes a variable that affects the process of achieving the identified organizational objectives when analyzed in the administration dimension of large-scale distance education institutions that try to provide educational services by completing intensive technology infrastructure investment (Daniel, 2010; Simonson, Smaldino $\&$ Zvacek, 2015).

Due to the nature of distance education, a single traditional organizational structure is not sufficient to provide the expectations of distance education institutions. For educational institutions providing distance education services, it is of great importance to develop an appropriate organizational structure in order to provide the expectations of the students which are the target of the education service. This situation emphasizes the strategic role of distance education administration process in open and distance education. As in other educational institutions, distance education institutions continue to exist with a system approach. Sub-systems such as preparation, distribution, administration of teaching and learning processes, budget preparation, development of technology infrastructure, development of student support services should be analyzed correctly within the scope of the administration of distance education institutions (Miller, 2010; Yavuzalp, 2019).

Distance education institutions have been pressured to provide the educational needs of very large masses of students in the uncertainty process created by the change process (Graham, 2019). For this reason, another important topic that comes to the forefront after leadership in the administration of distance education institutions is planning. The preparation of rational and updatable plans contributes to the achievement of the objectives of distance education institutions in the process of change positively (Simonson, Smaldino \& Zvacek, 2015).

With the adoption of the philosophy of innovation as in all educational institutions in institutions providing distance education services, it is of great importance to educate individuals who have adopted this philosophy. Investment in human resources needs to be increased day by day in the process of producing innovative ideas that can reveal new education models from the perspective of new technologies developing in distance education institutions and enable the distance education services to reach wide masses more rapidly and more effectively (Uzunboylu \& Tuncay, 2012). 
The sustainable implementation of student support services within the scope of the education services offered by distance education institutions is another important issue. The process of administration of distance education institutions should be investigated with the reality of intensive technology use. In this respect, the development of the technology infrastructure of distance education institutions highlights another issue that needs to be investigated in the administration process. Naturally, the intensity of technology use raises the need for continuous investments in technology infrastructure, and it is of great importance that economic issues related to cost are taken into account in the administration of distance education institutions (Simonson, Smaldino \& Zvacek, 2015).

Kaya $(2002$, p.65) classifies the services required by the institutions in the process of distance education administration in order to realize the determined aims of the institutions providing distance education services:

- Introduction activities about distance education services provided

- Development of course materials within the scope of distance education

- Storage facilities for distance education materials

- Distribution of course materials

- Evaluation of courses

- Consultancy services

- Provision of two-way communication between students and teaching staff

Each educational institution should choose educational software in accordance with its own philosophy, academic standards and curriculum. This is also valid for distance education institutions. If the educational needs are not centralized in the development of learning administration systems in the provision of educational services to the masses, problems may arise in the process of achieving the determined educational objectives. In addition, although the use of open source software in learning administration systems seems to have reduced the licensing cost for the existing educational service provider, the necessity of investing in selfdeveloped human resources according to the requirements of the era should not be ignored in the provision of distance education services through learning administration systems (Ozarslan \& Ozan, 2016).

The literature to date allows the summarization of the structure of distance education as follows (Holmberg, 1987, p.20):

- Philosophy and theory of distance education

- Remote students, their surrounding and its conditions and their motivation

- Communication and interaction between the university and the students

- Economics of distance education

- Systems (comparative distance education, types of instruction, etc.).

- History of distance education

- Organization and administration of distance education

The combined evaluation of studies conducted in a specific subject field provides certain scientific data regarding the general situation of research in that field. Meta-analysis or meta evaluation, which has been frequently used in the past twenty years of educational research in peer reviewed journals, allows for research to be studied collectively, providing positive contributions to researchers and educational policymakers on these subjects, and steering the course of future research and policies (Turan, Karadag, Bektas \& Yalcin, 2014).

To serve the purpose of this study, theses which would be within the scope of distance learning administration were analyzed within the scope of this study. It was determined that no previous study existed in which previous research on distance learning administration in Turkey was compiled and analyzed together. Therefore, the need for research in the field of distance learning administration in Turkey on previously conducted and prospective futures studies arose. 


\section{PURPOSE OF THE STUDY}

The purpose of this study is to assess the situation of distance learning administration in Turkey through the analysis of 145 theses (117 masters and 28 doctorate) written in the field between 1999-2019 regarding their methodologies, theoretical foundations, scopes, and policy recommendations to provide insight into future academic studies in the field. As such, the following research questions were posited.

Regarding published research in the field of Distance Learning Administration;

- How are they distributed in time?

- How are they distributed among institutes (graduate schools) and departments?

- What is the distribution of their subject matter?

- What is their methodological distribution?

- What is the distribution of their data sources?

- What is their distribution regarding data gathering tools?

- What is their distribution regarding data analysis?

- How are they distributed regarding policy recommendations they develop?

\section{METHODOLOGY}

In this section, the research model along with the methods used to determine the research included within the scope of this study are elaborated.

Within the scope of this study, theses published in the field of distance learning administration in Turkey within the years 1999-2019 were studied and the relationships between their methodologies, scopes, and policy recommendations were described, analyzed, and evaluated.

\section{Research Model}

Due to the goal of analyzing graduate theses published in the field of distance learning administration in Turkey between the years of 1999-2019, qualitative research method was used in this study. This research, which aims to study the methodological characteristics, scopes, and policy recommendations of graduate theses published in the field of distance learning administration in Turkey between 1999-2019, was conducted using document analysis based on qualitative data and the data gathered was analyzed using descriptive analysis (Yildirim \& Simsek, 2013).

Qualitative approaches to research value experiences and meaning, building a robust understanding of a topic through the activities, situations and meanings revealed or developed by people and objects. Relying on inductive designs to produce rich, descriptive data, qualitative researchers typically gather information in four ways: participation, observation, interviews, and document analysis (Leavy, 2017; Marshall \& Rossman, 2016).

Primary sources for collecting information include interviews, questionnaires and observations specifically undertaken for this purpose. Secondary sources refer to all other sources where the information is already available, such as previous studies and reports. In some cases, the vast number of previous studies in the same or a related field are sufficient to provide the required information (Kumar, 2011).

Practitioners in applied social sciences deal with everyday problems relating to social activity such as health and education. As these practitioners develop and gain experience, their understanding of the intricacies of the field lead to researchable questions, which in some cases may warrant a qualitative research design (Merriam \& Tisdell, 2016). 


\section{Determining the Studies}

The selection of the studies to be described, analyzed, and evaluated was based on certain criteria. These criteria were divided into three main categories: Chronology, theme, and place of publication.

The first fundamental criteria used to determine which research to include in this study was chronology. Studies were selected from research published between the years 1999-2019. The second criteria was the selection of studies published in the field of distance learning administration. The third criteria was the selection of theses openly accessible in the archives of the Turkish Higher Education Council Thesis Center.

\section{The Description, Analysis and Evaluation of Research}

The data gathered in this study was analyzed using descriptive analysis through the "Distance Learning Administration Research Evaluation Form" developed by the researcher. The theses selected for this study were firstly described. In this description stage, the "Distance Learning Administration Research Evaluation Form" was used for the analysis and thematization of each thesis based on; the significance (scope) of the thesis in the literature of distance learning administration, the date of the thesis, the methodology used, the data gathering resources, data gathering tools, analysis techniques, and policy recommendations.

\section{Validity and Reliability}

Validity and reliability in research is important for obtaining healthy results from a study. To ensure the internal validity of the study, a literature review was conducted, while the "Distance Learning Administration Research Evaluation Form" was used as a data gathering tool for the descriptive analysis. During the data analysis, experts in the field were consulted. Additionally, the researcher attempted to reduce bias during the coding of the data. No personal opinions were presented during the findings and results of the descriptive analysis of the data gathered using the "Distance Learning Administration Research Evaluation Form".

Due to the reliability requirements of descriptive analysis, different coders were requested to fill out the same evaluation form ("Distance Learning Administration Research Evaluation Form"), or the same coder was requested to fill the form at differing times. To ensure the reliability of this study, two experts in the field conducted coding in addition to the original researcher. The data gathered from the coding process were coded by two experts and researchers independently, establishing themes and sub themes. The selected coders were academics whom have conducted qualitative studies in the field of educational sciences. The themes and sub themes were re-established based on the common opinions of the experts. The coding was found to be a close fit to each other. The data was organized based on the themes and sub themes that emerged. Once a consensus was reached between the researcher and experts, a coding key was established. The reliability calculation of the study was determined using Miles \& Huberman's (1994, p.64) Intercoder Reliability [ $\mathrm{P}=$ $(\mathrm{Na} / \mathrm{Na}+\mathrm{Nd})$ x 100] (P: Consistency Percentage, Na: Consistency Quantity, Nd: Discrepancy Quantity). Once the reliability percentage was calculated for each question individually, a reliability ratio of $86 \%$ was determined to be sufficient to ensure the reliability of the study.

The coding of data following a descriptive analysis is necessary for several fundamental goals. Yildirim \& Simsek (2013) state these goals to be increasing reliability, reducing bias, drawing comparisons between themes or categories, and ensuring their use in possible repeat studies. In accordance with these coding goals, only frequency calculations were used in this study.

\section{FINDINGS AND INTERPRETATIONS}

The following table portrays the findings regarding theses included in this study openly accessible within the archives of the Turkish Higher Education Council Thesis Center. 
Table 1. Distribution of theses based on year

\begin{tabular}{|c|c|c|c|c|c|c|c|c|c|c|c|c|c|c|c|c|c|c|c|c|c|c|c|}
\hline & $\stackrel{\circ}{\bar{N}}$ & $\stackrel{\infty}{\stackrel{\infty}{N}}$ & $\hat{\bar{N}}$ & $\frac{0}{i}$ & $\stackrel{\text { Ln }}{\grave{N}}$ & $\frac{+}{i}$ & $\stackrel{m}{i}$ & $\stackrel{\sim}{\tilde{N}}$ & $\bar{i}$ & $\stackrel{\circ}{\circ}$ & ஜे & 怘 & 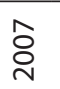 & ષ্ণ & 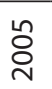 & ర্ণ & ஜ్ֶ & ర్రి & $\bar{d}$ & ষ্ণ & ूे & $\begin{array}{l}\overline{\widetilde{0}} \\
\stackrel{0}{0}\end{array}$ & \& \\
\hline Masters & 1 & 5 & 1 & 4 & 5 & 7 & 5 & 13 & 7 & 16 & 10 & 8 & 10 & 12 & 8 & 2 & 2 & 0 & 0 & 0 & 1 & 117 & 81 \\
\hline Doctorate & 0 & 3 & 2 & 0 & 3 & 3 & 5 & 1 & 2 & 0 & 1 & 1 & 5 & 0 & 1 & 0 & 0 & 0 & 0 & 0 & 1 & 28 & 19 \\
\hline Total & 1 & 8 & 3 & 4 & 8 & 10 & 10 & 14 & 9 & 16 & 11 & 9 & 15 & 12 & 9 & 2 & 2 & 0 & 0 & 0 & 2 & 145 & 100 \\
\hline$\circ^{\circ}$ & ó & $\stackrel{n}{n}_{n}^{n}$ & $\bar{i}$ & $\stackrel{\infty}{i}$ & n̊ $_{n}^{n}$ & જิ & જิ & $\hat{\sigma}$ & ชู & $\stackrel{-}{=}$ & $\stackrel{\circ}{\sim}$ & గુ & m. & $\underset{\infty}{m}$ & ָู & $=$ & $F$ & $0^{\circ}$ & $0^{\circ}$ & : & $\stackrel{\Xi}{=}$ & 8 & \\
\hline
\end{tabular}

Table 1 indicates that $81 \%$ of the theses conducted in distance learning administration are masters theses, while $19 \%$ are doctorate theses. From the year of publication data, it can be seen that no theses were published in the field of distance education between the years 2000-2002. With 106 theses published, 73\% of all theses were published between 2006-2014. The highest number of masters theses were published in 2010, and the highest number of doctorate theses were published in 2007 and 2013.

Table 2 portrays the evaluation results of the research in the field of distance learning administration regarding their institutes and departments.

Table 2. Distribution of theses based on institute and department

\begin{tabular}{|c|c|c|c|}
\hline Institute & Thesis Type & Department & $f$ \\
\hline \multirow{22}{*}{$\begin{array}{l}\text { Graduate School } \\
\text { of Science and } \\
\text { Technology }\end{array}$} & \multirow{6}{*}{ Doctorate } & Computer Engineering & 2 \\
\hline & & Informatics & 2 \\
\hline & & $\begin{array}{l}\text { Secondary Education Science and Mathematics } \\
\text { Teaching }\end{array}$ & 1 \\
\hline & & Electrical Education & 1 \\
\hline & & Industrial Engineering & 1 \\
\hline & & Environmental and Technical Research of Accidents & 1 \\
\hline & \multirow{19}{*}{ Masters } & & 13 \\
\hline & & Computer Engineering & 8 \\
\hline & & Electronics and Computer Education & \\
\hline & & Computer & 6 \\
\hline & & Computer Education and Instructional Technologies & 3 \\
\hline & & Electrical-Electronics Engineering & 2 \\
\hline & & Informatics & 2 \\
\hline & & Mathematics - Computer & 2 \\
\hline & & Mechanics Education & 2 \\
\hline & & Electrical Education & 2 \\
\hline & & $\begin{array}{l}\text { Information and Communication Technology } \\
\text { Systems Engineering }\end{array}$ & 1 \\
\hline & & Computer Education & 1 \\
\hline & & Electrical and Computer Engineering & 1 \\
\hline & & Computer and ICT Engineering & 1 \\
\hline & & Internet and ICT Management & 1 \\
\hline & & Statistics & 1 \\
\hline \multirow{3}{*}{$\begin{array}{l}\text { Graduate School } \\
\text { of Science and } \\
\text { Technology }\end{array}$} & & Traffic Planning and Execution & 1 \\
\hline & & Industrial Engineering & 1 \\
\hline & & Physics & 1 \\
\hline Total & & & 57 \\
\hline
\end{tabular}




\begin{tabular}{|c|c|c|c|}
\hline \multirow{23}{*}{$\begin{array}{l}\text { Graduate School of } \\
\text { Social Sciences }\end{array}$} & \multirow{4}{*}{ Doctorate } & Distance Education & 2 \\
\hline & & Information and Document Management & 2 \\
\hline & & Business & 1 \\
\hline & & Communication Sciences & 1 \\
\hline & \multirow{19}{*}{ Masters } & & 4 \\
\hline & & Business & 3 \\
\hline & & Computer Education and Instructional Technologies & 3 \\
\hline & & Distance Education & 2 \\
\hline & & Educational Sciences & 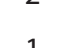 \\
\hline & & Journalism & 1 \\
\hline & & Business Administration & 1 \\
\hline & & Management Information Systems & 1 \\
\hline & & Educational Programs, Curriculum and Instruction & 1 \\
\hline & & Educational Administration and Supervision & 1 \\
\hline & & Economics & 1 \\
\hline & & Radio and Television & 1 \\
\hline & & Labour Economics and Industrial Relations & 1 \\
\hline & & Econometrics & 1 \\
\hline & & Communication Arts & 1 \\
\hline & & Philosophical and Theological Sciences & 1 \\
\hline & & Interior Architecture & 1 \\
\hline & & Slavic Languages and Literatures & 1 \\
\hline & & & 1 \\
\hline Total & & & 42 \\
\hline \multirow{11}{*}{$\begin{array}{l}\text { Graduate School of } \\
\text { Educational Sciences }\end{array}$} & \multirow{5}{*}{ Doctorate } & Computer Education and Instructional Technologies & 5 \\
\hline & & $\begin{array}{l}\text { Educational Administration, Supervision, Planning } \\
\text { and Economics }\end{array}$ & 3 \\
\hline & & Educational Programs, Curriculum and Instruction & 2 \\
\hline & & Educational Sciences & 1 \\
\hline & & Special Education & 1 \\
\hline & \multirow{6}{*}{ Masters } & Computer Education and Instructional Technologies & 12 \\
\hline & & Educational Sciences & 7 \\
\hline & & Office Management Education & 2 \\
\hline & & Assessment and Evaluation & 1 \\
\hline & & Business Education & 1 \\
\hline & & $\begin{array}{l}\text { Educational Administration, Supervision, Planning } \\
\text { and Economics }\end{array}$ & 1 \\
\hline Total & & & 36 \\
\hline \multirow{4}{*}{ Graduate School of ICTs } & Doctorate & Management Information Systems & 1 \\
\hline & \multirow{3}{*}{ Masters } & Management Information Systems & 3 \\
\hline & & Computer Education & 1 \\
\hline & & Electronic Computer Education & 1 \\
\hline \multirow[t]{2}{*}{ Total } & & & 6 \\
\hline & Doctorate & Nursing Instruction & 1 \\
\hline Graduate School of & & Medical Informatics & 1 \\
\hline \multirow[t]{2}{*}{ Health Sciences } & Masters & Health Education & 1 \\
\hline & & Medical Informatics & 1 \\
\hline Total & & & 6 \\
\hline Final Total & & & 145 \\
\hline
\end{tabular}


An analysis of the theses conducted in distance learning administration reveals that the highest number of theses were conducted within the Graduate Schools of Science and Technology. The number of theses in each graduate school from high to low were Science and Technology, Social Sciences, Educational Sciences, ICT, and Health Sciences.

Regarding doctorate theses, the highest number of doctorate theses (12) were prepared in Graduate Schools of Educational Sciences. The department within the Graduate Schools of Educational Sciences with the highest number of doctorate theses was Computer Education and Instructional Technologies.

Regarding masters theses, the highest number of masters theses (49) were prepared in the Graduate Schools of Science and Technology. The highest number of theses in the Graduate School of Science and Technology were prepared in the department of Computer Engineering. The institutes in which the most masters theses were prepared may be ranked from high to low as Science and Technology, Social Sciences, Educational Sciences, ICT, and Health Sciences.

\section{Research Scopes}

Table 3 portrays the evaluation results regarding the scopes of the studies conducted in the field of distance learning administration.

Table 3. Distribution of published studies in the field of distance learning administration based on sub themes

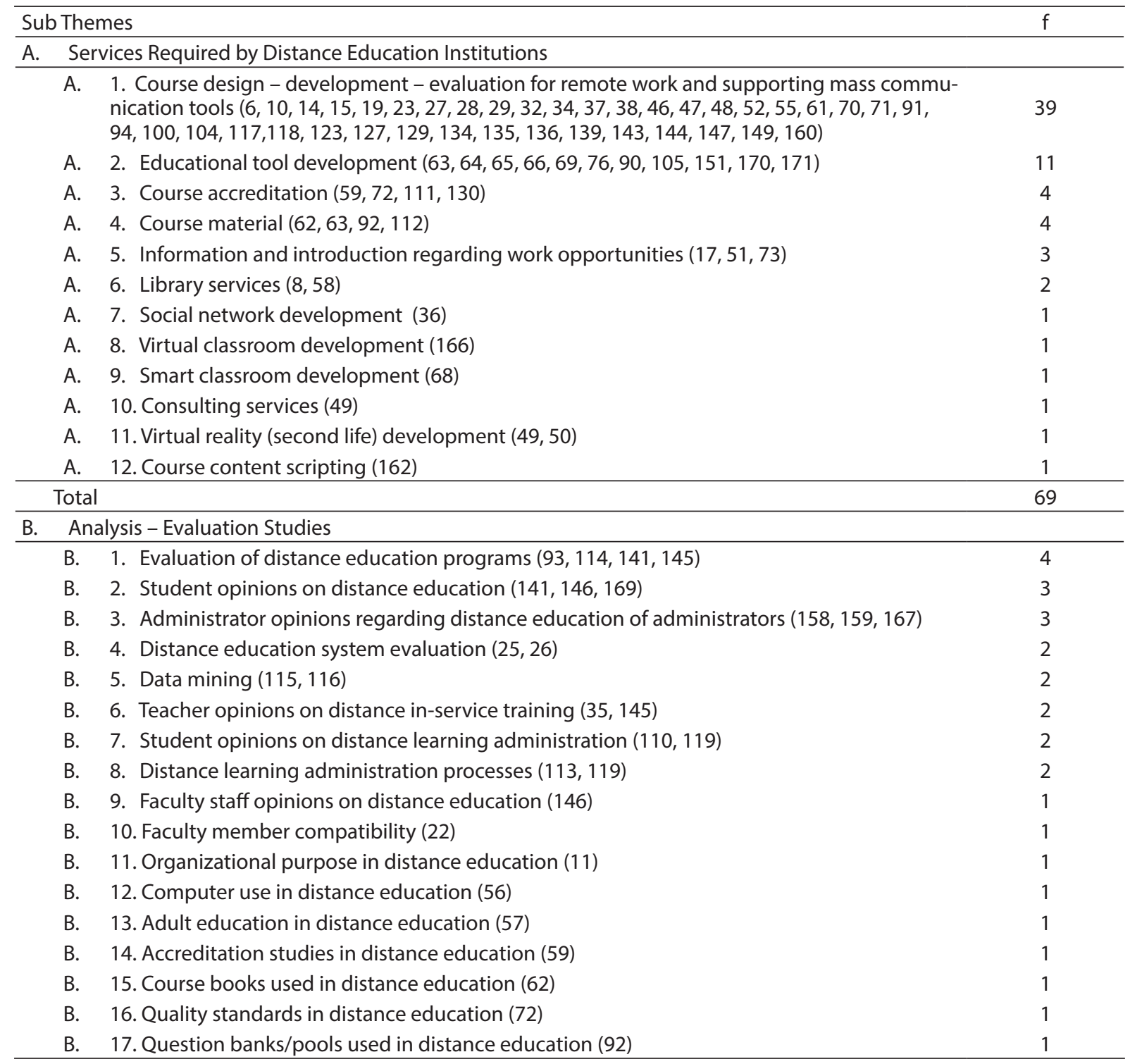




\begin{tabular}{|c|c|c|c|}
\hline & B. & 18. The configuration of learning management systems (96) & 1 \\
\hline & B. & 19. The selection of instruction management system (84) & 1 \\
\hline & B. & 20. Administrative mentality in distance education (109) & 1 \\
\hline & B. & 21. Leadership mentality in distance education (60) & 1 \\
\hline & B. & 22. Course material design criteria in distance education (142) & 1 \\
\hline & B. & 23. Use cases of mobile applications for vocational development (155) & 1 \\
\hline & B. & 24. Use cases of human resource information systems for vocational development (161) & 1 \\
\hline & B. & $\begin{array}{l}\text { 25. Influence of web based vocational development portal application on teaching skills of } \\
\text { teachers (165) }\end{array}$ & 1 \\
\hline & B. & 26. Analysis of web-based distance instruction system sample course (152) & 1 \\
\hline \multicolumn{2}{|c|}{ Total } & & 38 \\
\hline \multirow[t]{18}{*}{ C. } & Factc & ors Influencing Distance Education Services & \\
\hline & C. & 1. Academic achievement of students $(4,16,18,39,54,77,78,122,132)$ & 9 \\
\hline & C. & 2. Student attitudes $(97,122,140,167)$ & 4 \\
\hline & C. & 3. In-class participation/engagement - interaction $(16,18,77)$ & 3 \\
\hline & C. & 4. Applicability of distance education course $(2,9,98)$ & 3 \\
\hline & C. & 5. Technology use intentions of students $(87,120)$ & 2 \\
\hline & $\begin{array}{l}\text { A. } \\
\text { C. }\end{array}$ & 6. Functionality of distance education course (7) & 1 \\
\hline & C. & 7. Students' self-efficacy beliefs (167) & 1 \\
\hline & C. & 8. Technical infrastructure costs of distance learning administration (163) & 1 \\
\hline & C. & 9. Per-unit costs of students studying using distance learning administration (163) & 1 \\
\hline & C. & 10. The cost of distance education (163) & 1 \\
\hline & C. & 11. Profitability of prospective investment in distance education (163) & 1 \\
\hline & C. & 12. Technology use efficacies of students (95) & 1 \\
\hline & C. & 13. Usability level of distance education system (103) & 1 \\
\hline & C. & 14. Inclinations of faculty regarding web-based distance education tools (140) & 1 \\
\hline & C. & 15. Effectiveness of distance education applications (99) & 1 \\
\hline & C. & 16. Employment (161) & 1 \\
\hline & \multicolumn{2}{|c|}{ Total } & 32 \\
\hline \multirow[t]{7}{*}{ D. } & \multicolumn{2}{|r|}{ Problems Encountered in Distance Learning Administration } & \\
\hline & D. & 1. Accreditation issues of distance education $(59,111,130)$ & 3 \\
\hline & D. & 2. Student dropout issues in distance education $(1,17)$ & 2 \\
\hline & D. & 3. Administrative issues $(42,130)$ & 2 \\
\hline & D. & 4. Faculty compatibility/adaptation issues (22) & 1 \\
\hline & D. & 5. Accessibility issues (7) & 1 \\
\hline & \multicolumn{2}{|c|}{ Total } & 9 \\
\hline \multirow[t]{4}{*}{ E. } & \multicolumn{2}{|r|}{ Proposal Development Studies } & \\
\hline & E. & 1. Model proposal development $(5,8,24,30,53,109,131,138,150,154,157,172)$, & 12 \\
\hline & E. & 2. Distance in-service training program proposal development $(128,153)$ & 1 \\
\hline & \multicolumn{2}{|r|}{ Total } & 13 \\
\hline \multirow[t]{4}{*}{ F. } & \multicolumn{2}{|c|}{ Comparative/comparison Studies } & \\
\hline & F. & 1. Comparing instruction methods $(30,40,126,137,138,148,172)$ & 7 \\
\hline & F. & 2. Comparing distance education strategies/strategic plans (173) & 1 \\
\hline & F. & 3. Comparing distance education learning management systems (101) & 1 \\
\hline \multirow{2}{*}{\multicolumn{2}{|c|}{ Total }} & & 9 \\
\hline & & Tot & 170 \\
\hline
\end{tabular}

Analyzing the distribution of subjects in studies in the field of distance learning administration reveals thesis subjects to gather under 6 main themes. These themes, in decreasing order, were "services required by distance education institutions, analysis - evaluation studies, factors influencing distance education services, problems encountered in distance learning administration, recommendation development studies, and comparative/comparison studies".

The most frequently researched subject regarding services required by distance education institutions was course design - development - evaluation for distance education. The two other most frequently studied 
subjects under this theme were educational tool development and course accreditation. The most studied subject in analysis - evaluation research was the evaluation of the effectiveness of distance education programs. The two other subjects with the highest frequency were student opinions on distance education and administrator opinions on distance education of administrators.

The most studied subjects in factors influencing distance education services was academic achievement of students, followed by student attitudes and in-class participation/engagement - interaction. The most frequent subjects in research on problems faced in distance learning administration were, in descending order, distance education accreditation issues, students leaving distance education, and administrative issues.

The two subjects researched in proposal studies were, in descending order, model proposals and in-service training proposals. The subject matter of comparative studies from most frequent to least were comparisons of instruction methods, comparisons of distance education strategic plans, and comparisons of distance education learning management systems.

\section{Research Methodologies}

Table 4 indicates the evaluation results regarding research methods used in studies conducted in the field of distance learning administration.

Table 4. Models used in research

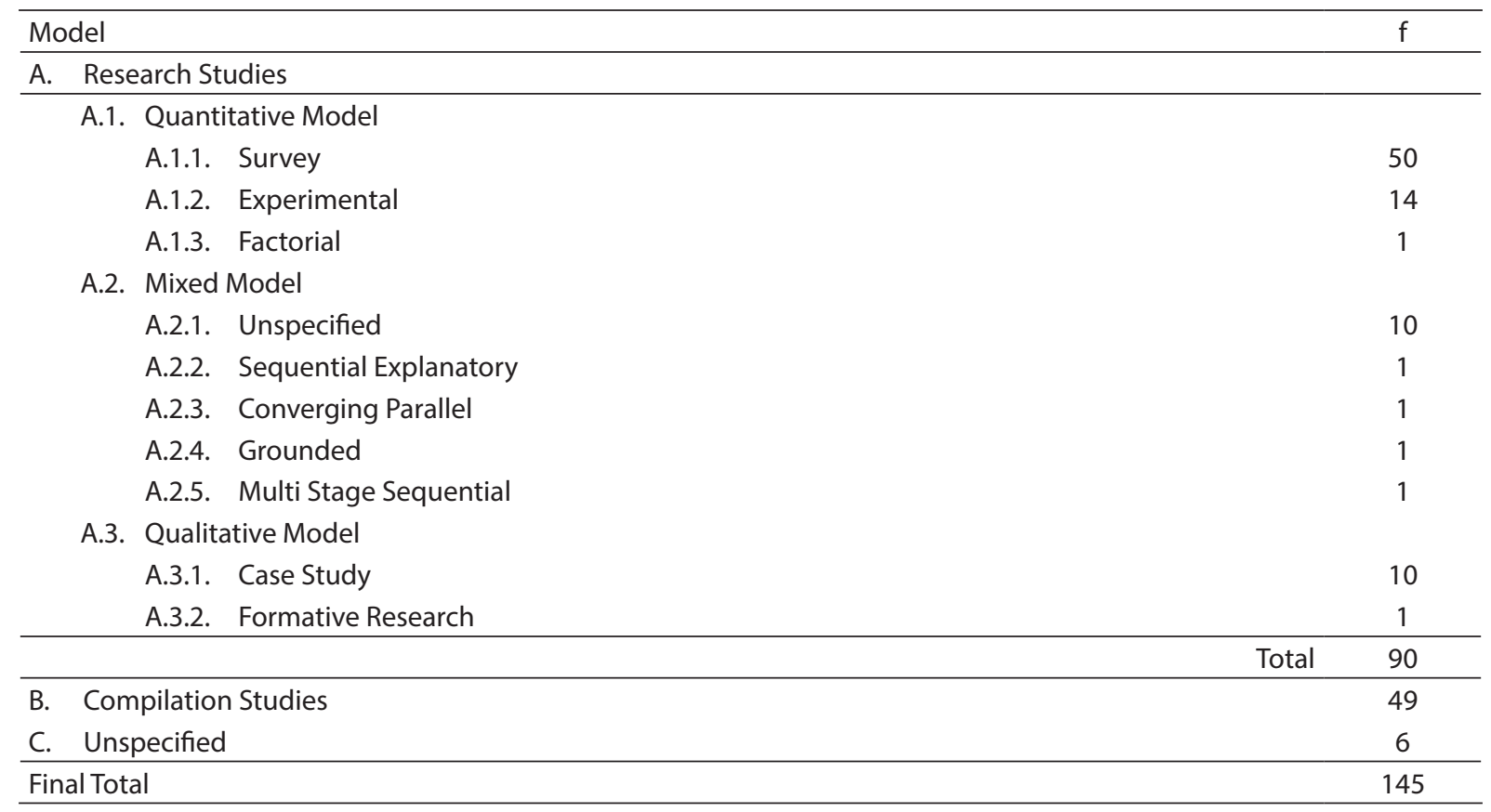

An analysis of the theses published in the field of distance learning administration indicates that these theses may be divided into two groups, namely original research and compilations or collected works. No explanation was found regarding the research methodology of 6 theses. Among research studies, quantitative research models were the most frequently used research designs, followed by mixed method research and lastly qualitative research designs.

\section{Data Sources of the Studies}

Table 5 shows the evaluation results regarding the data sources utilized for studies in the field of distance learning administration. 
Table 5. Research data sources

\begin{tabular}{ll}
\hline Data Sources & $f$ \\
\hline A. Student & 31 \\
A.1. Undergraduate & 14 \\
A.2. Junior College & 6 \\
A.3. Masters & 3 \\
A.4. High School & 2 \\
A.5. Secondary School & 1 \\
A.6. Primary School & 1 \\
A.7. Preschool & 26 \\
B. Unspecified & 19 \\
C. Faculty Member & 13 \\
D. Administrator & 10 \\
E. Document & 7 \\
F. Teacher & 7 \\
G. Personnel & 4 \\
H. Specialist & 1 \\
I. Parent & 145 \\
\hline Total
\end{tabular}

Analysis of these findings indicates students to be the primary data source for research, with the education levels of these students in decreasing order being undergraduate, junior college, and masters students. One of the two more interesting findings of this evaluation is that 26 of the theses provided no explanation regarding their data sources. The other is that an insufficient amount of data was gathered from the parents of students considering their important role as stakeholders in the educational system.

\section{Data Gathering Tools}

Table 6 portrays the evaluation results of the data gathering tools used in studies in the field of distance learning administration.

Table 6. Data gathering tools used in research

\begin{tabular}{|c|c|c|}
\hline \multicolumn{2}{|c|}{ Data Gathering Tools } & \multirow{2}{*}{$\begin{array}{c}f \\
43\end{array}$} \\
\hline A. & Survey Form & \\
\hline B. & Unspecified & 25 \\
\hline C. & Interview Form & 19 \\
\hline D. & Achievement Test & 14 \\
\hline E. & Document & 11 \\
\hline $\mathrm{F}$. & e-Survey Form & 11 \\
\hline G. & Scale Form & 8 \\
\hline $\mathrm{H}$. & Open-ended Survey Form & 6 \\
\hline I. & System Logs & 3 \\
\hline J. & Observation Form & 2 \\
\hline $\mathrm{K}$. & Retention Test & 1 \\
\hline $\mathrm{L}$. & Examination Form & 1 \\
\hline M. & Evaluation Form & 1 \\
\hline N. & Invantory & 1 \\
\hline Total & & 146 \\
\hline
\end{tabular}


An analysis of the data gathering tools used in distance learning administration research shows that survey forms are the most frequently used data gathering tools, followed in decreasing order by interview forms, achievement tests, documents, and scale forms. The least utilized data gathering tools in thesis studies in decreasing order were system logs, observation forms, retention tests, examination forms, and evaluation forms.

\section{Analysis Techniques of Research}

Table 7 shows the evaluation results regarding the analysis techniques utilized in research conducted in the field of distance learning administration.

Table 7. Analysis technics used in research

\begin{tabular}{|c|c|c|}
\hline \multicolumn{2}{|c|}{ Analysis Technics } & \multirow{2}{*}{$\frac{f}{68}$} \\
\hline A. & Descriptive Analysis (Percentage - Frequency) & \\
\hline B. & $\mathrm{t}$-Test & 22 \\
\hline C. & One-way ANOVA & 17 \\
\hline D. & Document Analysis & 13 \\
\hline E. & Factor Analysis & 11 \\
\hline F. & Content Analysis & 11 \\
\hline G. & Correlation Analysis & 10 \\
\hline $\mathrm{H}$. & Chi-squared Test & 10 \\
\hline I. & Regression Analysis & 7 \\
\hline J. & Wilcoxon W Test & 7 \\
\hline $\mathrm{K}$. & Kolmogorov Test & 4 \\
\hline L. & Smirnov Z Test & 4 \\
\hline M. & Mann-Whitney U Test & 3 \\
\hline $\mathrm{N}$. & Delphi Technique & 3 \\
\hline O. & Kruskal-Wallis H Test & 3 \\
\hline P. & Path Analysis & 2 \\
\hline Q. & Two-way ANOVA & 1 \\
\hline R. & Shapiro-Wilk Test & 1 \\
\hline S. & Box's M Test & 1 \\
\hline T. & Scheffé Test & 1 \\
\hline U. & Economic Analysis & 1 \\
\hline Total & & 200 \\
\hline
\end{tabular}

The analysis techniques used in theses in the field of distance learning administration indicates the most frequently used technique to be descriptive analysis. This was followed in decreasing order by t-Tests, analysis of variance, document analysis, factor analysis, content analysis, correlation analysis, chi-squared test, and regression analysis.

\section{Policy Recommendations of Studies}

Table 8 portrays the policy recommendations made in studies on distance learning administration. 
Table 8. Policy recommendations based on findings of the study

A. Policy Recommendations for Services Required by Distance Education Institutions

A. 1. Consider student preferences and expectations when developing content

A. 2. Orientation programs for students should be organized

A. 3. Students should be provided with technical support

A. 4. Course content should be developed to be interactive

A. 5. Design and software teams should be established in distance education centers

A. 6. Educational videos should be emphasized

A. 7. Counselling rooms in which students can receive face to face counselling should be established

A. 8. Content should be prepared appropriately for the levels and readiness of students

A. 9. The needs and requirements of disabled students should be considered when courses are being developed

A. 10. Personalization options (page arrangement, color, structural elements) may be included during course development

A. 11. Care should be given regarding making content accessible

A. 12. Distance education institutions should consider learner needs when establishing their goals and have open, concrete, measurable values

A. 13. Distance education systems should be accessible through mobile devices

A. 14. Libraries should add educational functions to their duties and the necessary infrastructure work should be conducted

A. 15. Steps should be taken to provide students with toll free numbers they can call for counseling services

A.16. Content should be prepared in accordance with general design principles

A. 17. The subject matter of the courses should be supported with multimedia elements and examples from everyday life

A. 18. Student progress may be monitored by expert auditors sent from higher institutions

A. 19. Connections may be established between distance education applications and social media platforms

A. 20. Detailed search features may be added to distance education systems to provide easy access to any content

A. 21. Distance education institutions should have their own strategic plans and should be encouraged to make strategic plans

A. 22. The Higher Education Council should assume duties regarding strategic planning in distance education

A. 23. The distance education strategic planning guide should be prepared with the support of the Higher Education Council and other institutions to ensure that distance education institutions prepare their distance education strategic plans in accordance with standards

A. 24. An institution determined by the Higher Education Council should oversee whether or not distance education strategic plans are in accordance with standards

A. 25. Having a distance education strategic plan should be a criteria in the accreditation of distance education institutions

A. 26. The vision, mission, and goals of the library should be determined in accordance with the needs of the students

A. 27. An educationalist should be included in the staff of distance education centers

A. 28. A classroom manager should be included in the staff of distance education centers

A. 29. The educational use of social networks should be adopted and private networks open only to members may be used

A. 30. The professional developments of teachers may be supported by the use of web based vocational development portals with coaching support

A. 31. Interactive content with real problems at schools combining theory and practice should be used when designing problem based learning problems for use in web based school administrator trainings

A. 32. Real world scenarios used in web based problem scripts should be used as evaluation tools in the examinations conducted for appointing administrators 
B. Policy Recommendations Regarding Factors Influencing Distance Education Services

B. 1. Interaction levels should be increased by ensuring students interact through elements such as chats, discussion boards, and face to face interactions

B. 2. Distance in service training may be used in the professional development of employees

B. 3. Educators should be informed regarding distance education services and technologies and their uses through in service training.

B. 4. Students should be provided basic computer training

B. 5. Distance in service training should be supported and encourage by the relevant institutions and organizations

B. 6. Ministries may establish distance (in service) education centers for the professional development of their own employees

B. 7. Immediate feedback should be provided to prevent wrong and incorrect learning

B. 8. Cost benefit analyses of distance education platforms should be conducted constantly for the professional development of employees

B. 9. The practice of professional encouragement (in career and performance evaluations) and institutional rewards should be extended and increased in distance education systems

B. 10. Before organizing distance in service training to employees, a needs analysis may be conducted to ensure training appropriate for the needs of the employees is provided

B. 11. Online classes at flexible hours should be provided to employees to increase academic achievement

B. 12. Motivation may be increased by informing students graduating form the program about work possibilities provided to them

B. 13. Distance education programs may be prepared with an interdisciplinary approach

B. 14. When developing distance education programs, the program should be established with a combination of a computer technologies expert, an adult education expert, a curriculum development and instruction expert, an assessment and evaluation expert, and a program content expert

B. 15. The learning fee payment method should vary based on student preference

ortant information and developments should be notified to the students through e-mail

B. 17. Students should be provided with scholarship opportunities

B. 18. Students should be made aware of their rights and responsibilities

B. 19. Associates, Bachelors or degree certificate programs should be established to train distance education administrators

B. 20. Family education programs may be organized using distance education for families who may not be reached due to various obstacles

C. Policy Recommendations Regarding Issues Faced in Distance Learning Administration

C. 1. Fulfilling the needs and constantly renewing the technical equipment, hardware, and software infrastructure requirements of distance education institutions

C. 2. The legal foundations regarding distance education institutions should be prepared and ratified as laws

C. 3. The system usage data of students such as degrees of use and duration of content consumption should be traceable within the system

C. 4. A help menu explaining the use of the distance education platform should be accessible from every screen or page

C. 5. The accreditation of distance education programs should be ensured

C. 6. A distance education consortium in which quality course content developed by different distance education centers is stored and shared may be established

C. 7. Distance education platforms should meet the required standards regarding design, content, and software quality

C. 8. When evaluating academic achievement, performance indicators focused on interaction should be determined and used in addition to examination and assignment scores

C. 9. Distance education institutions may use the Distance Education Evaluation Inventory to evaluate their own operations and determine their shortcomings

C. 10. Distance education institutions may provide their own distance education platforms to solve their infrastructure issues

C. 11. The behavioral and communication rules of online learning communities should be clearly stated, while communication rules should be established and adherence to these rules should be ensured

6

5

4

4

(1)




\begin{tabular}{|c|c|c|}
\hline & $\begin{array}{l}\text { C. 13. Increased security should be ensured by administering the required certificates to servers } \\
\text { and installing firewalls }\end{array}$ & 2 \\
\hline & $\begin{array}{l}\text { C. 14. Distance education institutions should hire experienced and professional staff and conduct } \\
\text { duty planning for their employees prior to initiating their programs }\end{array}$ & 2 \\
\hline & $\begin{array}{l}\text { C. 15. Simple, plain and understandable interface designs should be preferred to ease system } \\
\text { administrators }\end{array}$ & 2 \\
\hline & C. 16. Internet infrastructure providers should support distance education centers and students & 2 \\
\hline & C. 17. Transfer rights to and from face to face education institutions should be ensured & 1 \\
\hline & $\begin{array}{l}\text { C. 18. A national council may be established to solve issues regarding distance education institu- } \\
\text { tions }\end{array}$ & 1 \\
\hline & C. 19. An online attendance system may be introduced to distance education & 1 \\
\hline & $\begin{array}{l}\text { C. 20. Break/interval pages (humor, educational questions, puzzles, mental exercises, and music) } \\
\text { may be added }\end{array}$ & 1 \\
\hline & $\begin{array}{l}\text { C. 21. Distance education institutions should conduct infrastructure design unique to their institu- } \\
\text { tions }\end{array}$ & 1 \\
\hline & $\begin{array}{l}\text { C. 22. A distance education leader training program should be opened to manage distance educa- } \\
\text { tion centers }\end{array}$ & 1 \\
\hline & $\begin{array}{l}\text { C. 23. Faculty may be provided the opportunity to share their experiences with each other through } \\
\text { a platform to be developed between distance education institutions }\end{array}$ & 1 \\
\hline & C. 24. Free internet access centers should be established connected to distance education centers & 1 \\
\hline & C. 25. Face to face instruction should be provided during off-hours when required & 1 \\
\hline & $\begin{array}{l}\text { C. 26. For the effective use of the workforce of distance education institutions, distance education } \\
\text { centers managed by a single administrative unit should be established rather than provid- } \\
\text { ing distance education services through multiple units }\end{array}$ & 1 \\
\hline & $\begin{array}{l}\text { C. 27. Institutions may purchase a distance learning administration system that records participant } \\
\text { information and trainings, negating the need to pay the fees of companies that provide } \\
\text { technical support for each training individually }\end{array}$ & 1 \\
\hline & $\begin{array}{l}\text { C. 28. The training plan and course content may be announced to the participants prior to the start } \\
\text { of distance in service training courses }\end{array}$ & 1 \\
\hline Total & & 71 \\
\hline \multicolumn{2}{|c|}{ D. Unspecified } & 36 \\
\hline \multicolumn{2}{|c|}{ General Total } & 350 \\
\hline
\end{tabular}

The policy recommendations made in studies conducted in distance learning administration may be observed to have gathered under three categories. These categories, in decreasing frequency, were policy recommendations regarding services required by distance education institutions, policy recommendations regarding factors influencing distance education services, and policy recommendations regarding issues faced in distance learning administration.

The policies developed regarding services required by distance education institutions indicates an emphasis on student preference and expectations while developing content. The three following most recommended policies were orientation programs for students, technical support for students, and developing interactive course content.

The most frequent policy recommendation regarding factors influencing distance education services were chat, message board and face to face interaction and similar components ensuring student interaction. The three following recommendations in this regard were the use of distance in service training for the professional development of employees, educators being informed of distance education services and technology use through in service training, and providing students with fundamental computer training.

The policy recommendations developed regarding issues faced in distance learning administration were most frequently regarding meeting the technical equipment, hardware and software infrastructure needs of distance education institutions and their constant renewal. The three following recommendations based on frequency were the establishment and ratification of the legal foundations of distance education institutions, the determination of the degree to which students took advantage of the system, and tracking the selection and duration of content use by students in the system and providing help menus on every page explaining the use of the distance education platform. 


\section{CONCLUSION AND DISCUSSION}

Developing new technologies have surrounded the world with their effects. The speed of technological development is increasing day by day without any tendency to slow down and this increase affects all institutions intensively in the world. One of the most important focal points of this impact is higher education institutions. This situation imposes an important mission on higher education institutions in particular for educational institutions. Higher education institutions, which are the locomotives of the information society and undertake the responsibility of raising individuals suitable for the requirements of the age, must understand the change process correctly and develop the reflex to adapt to this process quickly. Because, in the reality of knowledge economy, universities are the most strategic institutions that are both producers and distributors of knowledge in the society (Bates, 2015).

Education is the most strategic factor that accelerates the adaptation process of all countries to the information age. In this context, education as a process also represents an important social institution that needs to be invested intensely. The rapid growth of the world's population may cause some limitations in providing the educational needs of all individuals rationally. In the process of providing educational services at low cost especially worldwide, it is of great importance to provide the lifelong learning needs of individuals in a fast and practical way. In addition, the effective use of scarce resources constitutes the focus of the educational policies determined by the countries. Some of the main problems experienced in the spread of educational services to society in the higher education level together with vocational and technical education lead the countries to new perspectives in the provision of educational services and one of the most popular of these perspectives is distance education (Isman, 2011).

In the twenty-first century, the technology-based change process has led to the emergence of alternative paradigms in the education and training processes of individuals through educational institutions. With the speed of change and aging of knowledge, individuals demand new information that will provide their own needs anytime and anywhere. This can be solved through a restructuring process that can meet the expectations for all educational institutions. When the issue is considered for distance education institutions, it is of great importance to develop student-centered, cost-effective learning environments that are open to interaction, meet current social expectations rapidly, especially in the administration of distance education institutions (Khan, 2005).

This study indicates that the research on distance learning administration accessible through the Turkish Higher Education Council Thesis Center archives comprise of 81\% masters theses and 19\% doctorate theses. The distribution of theses by year indicates that no thesis research was published on this subject between 2000-2002. With 106 studies published, 73\% of all published thesis research was published between 20062014. The highest number of masters theses was published in 2010, while the highest number of doctorate theses was published in 2007 and 2013.

Analysis of the theses in the field of distance learning administration indicates that the highest number of theses was prepared in Graduate Schools of Science and Technology. A rank of these institutes from high publication numbers to low would be as follows: Science and Technology, Social Sciences, Educational Sciences, ICT, and Health Sciences. With 12 published theses, the highest number of doctorate theses was conducted in Graduate Schools of Educational Sciences. The department in which the highest number of doctorate theses were published was Computer Education and Instructional Technologies. The graduate schools with the highest number of doctorate theses in the field in descending order were Educational Sciences, Science and Technology, Social Sciences, ICT, and Health Sciences.

With 49 published theses, the highest number of masters theses was conducted in Graduate Schools of Science and Technology. The department in which the highest number of masters theses were published was Computer Engineering. The graduate schools with the highest number of masters theses in the field in descending order were Science and Technology, Social Sciences, Educational Sciences, ICT, and Health Sciences. The department within Graduate Schools of Science and Technology with the highest number of doctorate and masters theses was computer engineering.

The department within Graduate Schools of Social Science with the highest number of doctorate theses was Distance Education; the department with the highest number of masters theses was Business. The department within Graduate Schools of Educational Sciences with the highest number of doctorate and 
masters theses was Computer Education and Instructional Technologies. The department within Graduate Schools of ICT with the highest number of doctorate and masters theses was Administrative ICT systems. The department within Graduate Schools of Health Sciences with the highest number of doctorate theses was Nursing Education; the department with the highest number of masters theses was Medical ICT.

The distribution of subjects in the field of distance learning administration indicates that theses revolve mainly around 6 main themes. These subjects, in decreasing number, were services required by distance education institutions, analysis-evaluation studies, factors influencing distance education services, issues faced in distance learning administration, policy recommendation development studies, and comparative studies. No other research was found evaluating the subjects of research in distance learning administration in Turkey.

The most frequently studied subject regarding services required by distance education institutions was course design - development - evaluation. The following two subjects were developing educational tools, and course accreditation. The most frequently studied subject regarding analysis-evaluation studies was the evaluation of the effectiveness of distance education programs. The following two subjects were student opinions on distance education, and administrator opinions on management education at a distance.

The most frequently studied subject regarding factors influencing distance education services was the academic achievement of students. The following two subjects were student attitudes, and course participation/ engagement - interaction. The most frequently studied subject regarding issues faced in distance learning administration was accreditation issues in distance education. The following two subjects were student drop out issues, and administrative issues.

The most frequently subjects regarding policy recommendation development studies were, in decreasing order, model proposal development, and in service training program proposal development. The subjects studied in comparative research in decreasing order were comparisons of instructional methods, comparisons of distance education strategic plans, and comparisons of learning management systems in distance education. Analysis of the methodologies of the theses conducted in the field of distance learning administration reveals that studies may be gathered in two groups: original research and compilation studies. 6 theses provided no information regarding the methodology of the study.

$47 \%$ of the studies in distance learning administration were conducted using quantitative research models, $8 \%$ used qualitative models, $35 \%$ were compilations and $10 \%$ used mixed methods. Within the scope of this study, it may be stated from the findings that the frequently utilized quantitative, qualitative and compilation studies comprised mostly of descriptive studies, which is similar to the results of Turan et. al. (2014), who studied the methodologies of studies in educational administration. They found that research frequently was conducted using quantitative, qualitative and compliation methods. Another finding supported by the findings of Turan et. al. was that there were few qualitative and mixed model studies.

This study revealed that of the frequently used quantitative models in this field of research, survey methods were most frequently used. This finding is similar to the findings of Aypay et. al. (2010), who concluded that surveys were frequently used in the field of educational administration. No other evaluation study regarding frequently used quantitative models in the field was found.

The findings of this study indicate that nearly all of the qualitative research in this field were case studies. Only one study used formative research as a method. No similar research regarding the frequently used quantitative models in the field was found. Regarding the data sources for theses in distance learning administration, students were the most frequently utilized source of data. The status of students who provided data in decreasing order was bachelor, associate, and masters students.

Two interesting findings of this study were that 26 theses provided no information regarding their data sources, and secondly the fact that despite being an important stakeholder in the educational system, not enough data was gathered from parents of students. Within the scope of the findings it may be stated that primary data sources such as student bodies and secondary data sources such as documents were the most frequently used data sources, which coincides with the findings of Turan et. al. (2014), who also found that students and secondary sources were the most utilized data sources. The analysis in this study determined the most frequently utilized primary data sources were students, administrators, teachers, and faculty, a finding which supports the results of Aypay et. al. (2010). 
An analysis of the data gathering tools used in theses in the field of distance learning administration shows that survey forms are the most frequently used data gathering tools, followed by interview forms, achievement tests, documents, and scale forms. The least used data gathering tools in theses were system logs, observation forms, permanence/retention tests, examinations, and evaluation forms.

No other evaluation study regarding the analysis techniques used in research was found in the literature of the field. The policy recommendations developed regarding distance learning administration may be gathered under three categories (in decreasing order): policy recommendations regarding services required by distance education institutions, policy recommendations regarding factors influencing distance education services, and policy recommendations regarding issues faced in distance learning administration.

The most frequent policy recommendation regarding services required by distance education institutions was the consideration of student preference and expectations while developing content. This was followed in decreasing order by orientation programs for students, technical support for students, and the development of interactive course content. Regarding policy recommendations for factors influencing distance education services, the most frequent recommendation was ensuring and increasing student interaction through components such as chat rooms, discussion boards, and face to face interaction. This was followed by the use of distance in service training for professional development of employees, informing educators about distance education services and technologies through in service training, and basic computer training for students.

The policy recommendations developed regarding issues faced in distance learning administration indicates that the primary recommendation was meeting the technical equipment, hardware and software infrastructure needs of distance education institutions and keeping these provisions up to date through maintenance and renewal. This was followed by the preparation and ratification of a legal basis for distance education institutions, determining the degree to which students take advantage of the system along with tracking content preference and usage duration data through the system, and providing a help menu on every page regarding the use of the distance education platform. An analysis of the meta evaluation studies in the literature revealed that no similar finding was obtained regarding the compiled evaluation of policy recommendations.

\section{BIODATA and CONTACT ADDRESSES of AUTHOR}

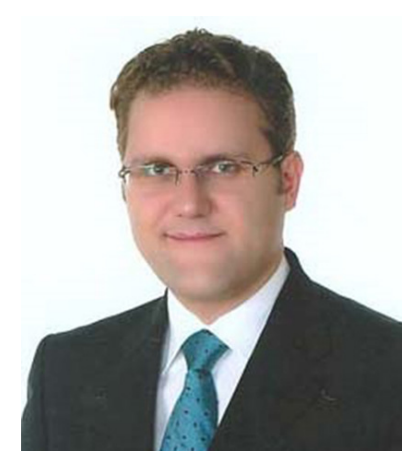

Dr. Eren KESIM, is faculty member of the Anadolu University Faculty of Education, Department of Educational Sciences and Division of Educational Administration. He graduated from the Anadolu University Faculty of Economics and Administrative Sciences, Department of Economics in 2001. He continued to study at the Anadolu University Institute of Educational Sciences in the field of Educational Administration, Supervision, Planning and Economics. He received his Master degree in 2004, and his doctorate degree in 2009. His academic research continues in the fields of economics of education, economics of distance education, educational administration, educational technology management and the training of school principals.

\section{Eren KESIM}

Anadolu University, Faculty of Education Address: Anadolu University, Faculty of Education, Yunusemre Campus, 26470, Tepebasi, Eskisehir, TURKEY Phone: +90 $2223350580 / 3466$

e-mail: ekesim@anadolu.edu.tr 


\section{REFERENCES}

Aydin, M. (2014). Egitim yonetimi [Educational administration]. (10. baski). Ankara: Gazi Kitabevi.

Aypay, A., Coruk, A., Yazgan, D., Kartal, O., Cagatay, M., Tuncer, B., \& Emran, B. (2010). The status of research in educational administration: An analysis of educational administration journals, 19992007. Eurasian journal of educational research, 39, 59-77.

Balci, A. (2019). Aciklamali egitim yonetimi terimleri sozlugu [Annotated dictionary of educational administration terms] (4. baski). Ankara: Pegem Akademi.

Bates, T. (2015). Teaching in a digital age: Guidelines for designing teaching and learning. Vancouver : BCcampus Open Textbooks.

Daniel, J. S. (2010). Mega-schools, technology and teachers. Achieving education for all. New York: Routledge.

Firat, M. (2019). Uygulamadan kurama acik ve uzaktan ogrenme. [Open and distance learning from practice to theory]. Ankara: Nobel Yayincilik.

Gedikoglu, T. (2015). Liderlik ve okul yonetimi [Leadership and school management]. Ankara: Ani Yayincilik.

Graham, C.R. (2019). Current research in blended learning. In M.G. Moore \& W. C. Diehl (Eds.), Handbook of Distance Education (pp.173-188). (Fourth Edition). Newyork \& London: Routledge.

Holmberg, B. (1987). The development of distance education research. American Journal of Distance Education, 1 (3), 16-23. Retrieved September 10, 2019 from https://www.tandfonline.com/doi/ abs/10.1080/08923648709526594

Isman, A. (2011). Uzaktan egitim [Distance education]. (4. baski). Ankara: Pegem Akademi.

Kaya, Z. (2002). Uzaktan egitim [Distance education]. Ankara: Pegem A Yayincilik.

Khan, B. (2005). Managing e-learning strategies: Design, delivery, implementation and evolution. Hershey, PA: Information Science Publishing.

Kumar, R. (2011). Research methodology: A step-by-step guide for beginners. (3th edition). London: Sage Publications.

Leavy, P. (2017). Research design. Quantitative, qualitative, mixed methods, arts-based and community-based participatory research approaches. New York: The Guilford Press.

Marshall, C., \& Rossman, G.B. (2016) Designing qualitative research. (6th edition). Los Angeles, California: Sage Publications.

Merriam, S.B., \& Tisdell, E.J. (2016). Qualitative research: A guide to design and implementation. (4th edition). San Francisco, CA: Jossey-Bass.

Miles, M.B., \& Huberman, A.M. (1994). Qualitative data analysis: An expanded sourcebook. (2nd edition). Thousand Oaks, California: Sage Publications.

Miller, G.E. (2010). Organization and technology of distance education. In M.F. Cleveland-Innes \& D.R. Garrison (Eds.), An introduction to distance education. Understanding teaching and learning in a new era (pp.26-45). New York \& London: Routledge.

Ozarslan, Y. \& Ozan, O. (2016). Ogrenme yonetim sistemleri. [Learning management systems]. Ankara: Detay Yayincilik.

Selwyn, N. (2016). Is technology good for education? Cambridge: Polity Press.

Simonson, M., Smaldino, S., \& Zvacek, S. (2015). Teaching and learning at a distance. Foundations of distance education. (6th edition). Charlotte, North Carolina. IAP-Information Age Publishing, Inc.

Uzunboylu, H. \& Tuncay, N. (2012). Uzaktan egitimde sanal degisimler [Virtual changes in distance education]. Ankara: Pegem Akademi. 
Turan, S., Karadag, E., Bektas, F., \& Yalcin, M. (2014). Turkiye'de egitim yonetiminde bilgi uretimi: Kuram ve Uygulamada Egitim Yonetimi Dergisi 2003-2013 yayinlarinin incelenmesi. [Knowledge production in educational administration in Turkey: An overview of researches in Journal of Educational Administration: Theory and practice -2003 to 2013]. Kuram ve Uygulamada Egitim Yonetimi [Educational Administration: Theory and Practice], 20(1), 93-119. doi: 10.14527/ kuey.2014.005

Wheeler, S. (2015). Learning with 'es. Educational theory and practice in the digital age. Carmarthen: Crown House Publishing.

Yavuzalp, N. (2019). Acik ve uzaktan ogretim yonetimi [The management of teaching in open and distance learning]. In E. Tekinarslan \& M.D. Gurer (Eds.). Acik ve uzaktan ogrenme [Open and distance learning] (pp.145-172). (2. baski). Ankara: Pegem Akademi.

Yildirim, A., \& Simsek, H. (2013). Sosyal bilimlerde nitel arastirma yontemleri [Qualitative research methods for social sciences]. (9. baski). Ankara: Seckin Yayinevi. 